\title{
Quantification of Magnaporthe grisea During Infection of Rice Plants Using Real-Time Polymerase Chain Reaction and Northern Blot/Phosphoimaging Analyses
}

\author{
Min Qi and Yinong Yang
}

Department of Plant Pathology, University of Arkansas, Fayetteville 72701.

Current address of M. Qi: Ceres Inc., 3007 Malibu Canyon Road, Malibu, CA 90265.

Accepted for publication 17 April 2002.

\begin{abstract}
Qi, M., and Yang, Y. 2002. Quantification of Magnaporthe grisea during infection of rice plants using real-time polymerase chain reaction and northern blot/phosphoimaging analyses. Phytopathology 92:870-876.

Rice blast, caused by Magnaporthe grisea, is a serious fungal disease of rice worldwide. Currently, evaluation of the fungal pathogenicity and host resistance is mainly based on a disease rating or measurement of blast lesion number and size. However, these methods only provide visual estimation rather than accurate measurement of fungal growth in rice plants. In this study, DNA-based real-time polymerase chain reaction (PCR) and RNA-based northern blot/phosphoimaging analyses were evaluated to quantify $M$. grisea. Both methods were sensitive, specific, and reproducible and could accurately measure the relative growth and
\end{abstract}

ABSTRACT absolute biomass of $M$. grisea. The real-time PCR analysis showed that the growth of M. grisea in seedling leaves of susceptible cultivars (M201 and Wells) was $\approx 46$ to 80 times higher than that of a resistant cultivar (Drew) at 4 and 6 days after inoculation. The data obtained from the realtime PCR assays also were consistent with that from northern blot/ phosphoimaging analysis. However, the real-time PCR approach was much faster and more convenient in most cases. Therefore, it is an excellent tool for in planta quantification of $M$. grisea and can be used for reliable assessment of fungal pathogenicity and host resistance.

Additional keywords: disease resistance, Oryza sativa, Pyricularia grisea, virulence.
In the study of plant-fungus interactions, a rapid and accurate measurement of fungal growth in planta often is required to adequately evaluate fungal pathogenicity and host resistance. Various methods have been developed to detect and quantify fungal pathogens in plant and soil environments. For example, total fungal biomass has been estimated by measuring levels of fungal constituents such as ergosterol or chitin $(10,11,26,32,33)$. This method often lacks specificity and does not always correlate with the fungal biomass due to fungal sporulation and interference from enzymatic activities in plants $(5,40)$. Immunological methods also have been used for fungal biomass determination $(8,14,21,30)$. However, it is generally difficult to obtain antibodies with the required specificity for particular fungi (45). In addition, immunoassays often are complicated by false-positive reactions $(39,41)$. Many studies have used GUS (a bacterial $\beta$-glucuronidase gene) -transformed strains to quantify fungal biomass in plants $(1,7,20$, $22,31,44)$. Although these genetically modified strains offer relatively easy and quick quantification of fungi in plants, the biggest disadvantage of this method is the requirement of transgenic fungi that are not available in most cases. There are also great concerns for using transgenic fungi in field trials because of environmental consideration. Furthermore, several researchers have reported that the GUS enzyme was not always an adequate marker for necrotrophic pathogens, because GUS activity did not correlate with the fungal biomass due to inactivation of GUS enzyme in the lesion $(4,43)$.

During the past several years, the polymerase chain reaction (PCR) method has emerged as a major tool to detect and identify

Corresponding author: Y. Yang; E-mail address: yiyang@uark.edu

Publication no. P-2002-0610-01R

(C) 2002 The American Phytopathological Society fungal pathogens. Specific primers can be designed to distinguish closely related fungal species; therefore, it offers higher sensitivity and specificity than many other methods (16). A number of studies have used quantitative PCR to measure plant pathogenic fungi during fungus-plant interactions $(12,18,19,24)$. However, such quantitative data is not directly derived from target DNAs but from the ratio between target and competitor DNAs. It also needs additional post-PCR confirmation steps such as running gels and image processing. More recently, the real-time PCR technique has been developed to detect and quantify DNAs (15). This technique combines thermal cycling with online fluorescence detection of the PCR amplification and records a specific cycle number, in term of cycle threshold $(\mathrm{Ct})$, at which a statistically significant increase in the fluorescence (just greater than the background) can first be detected. The $\mathrm{Ct}$ is inversely proportional to the log of the initial template of DNA. The more templates that are initially present in PCR samples, the smaller the $\mathrm{Ct}$ it takes to get to a point where the fluorescent signal is detectable above background. The $\mathrm{Ct}$ value has been shown to be the most reliable parameter to detect and quantify target DNAs with real-time PCR (15). The quantitative data based on $\mathrm{Ct}$ is more accurate than data derived from endpoint determinations because $\mathrm{Ct}$ is a measurement taken during the exponential phase of PCR amplification when the PCR efficiency has yet to be influenced by limiting reagents, small differences in reaction components, or cycling conditions. As a result, real-time PCR technique has been increasingly used to detect or quantify viral, bacterial, and fungal plant pathogens $(2,3,6,9$, 28,34,36,46).

Among RNA-based methods, northern blot analysis has been used to quantify fungal biomass in infected plants by measuring the constitutive expression of fungal genes such as actin, $\beta$-tubulin, and rRNA genes $(4,23,27)$. During the infection, the amount of fungal biomass increases with time in infected tissues. Conse- 
quently, the proportion of certain fungal RNAs increase with time in total RNAs extracted from infected plant tissues. Thus, the level of constitutively expressed fungal genes could be used to calculate fungal biomass in infected plants.

Rice blast, caused by Magnaporthe grisea (T. T. Hebert) Yaegashi \& Udagawa (anamorph Pyricularia grisea (Cooke) Sacc.), is a serious fungal disease that has a significant negative impact on rice production in the world. The blast fungus can penetrate directly through the outer cell wall into epidermal cells and grow intracellularly and intercellularly (17). Up-to-date evaluation of the fungal pathogenicity and host resistance is mainly based on disease ratings or measurements of blast lesion number and size $(13,37,38)$. Although these methods are quick and easy to perform, they only provide a visual estimation rather than an accurate measurement of $M$. grisea growth in rice plants. In this study, we have evaluated DNA-based real-time PCR and RNA-based northern blot/phosphoimaging analyses for the quantification of $M$. grisea growth. A pair of DNA primers and a 330-bp probe were designed based on the $3^{\prime}$ end of $M$. grisea $28 \mathrm{~S}$ ribosomal gene $(r D N A)$ and tested for detection sensitivity and specificity. The reproducibility and consistency of both methods have been verified and compared. Furthermore, DNA and RNA standard curves were constructed to facilitate the calculation of relative fungal growth or absolute biomass. We have demonstrated that both methods can be used to reliably quantify the growth of $M$. grisea in rice plants.

\section{MATERIALS AND METHODS}

Fungal isolate and plant materials. The fungal isolate used in this study belongs to the IC-17 pathotype of $M$. grisea. The blast fungus was grown at $24^{\circ} \mathrm{C}$ for 5 days in a previously described medium broth (13). Mycelia were harvested and washed twice with sterilized water by filtration through a Buchner funnel onto Whatman filter paper. Fungal mycelia then were blotted dry and weighed. For DNA extraction, fungal mycelia were freeze dried, weighed, and then stored at $-80^{\circ} \mathrm{C}$. For RNA extraction, fresh mycelia were immediately frozen with liquid nitrogen and stored at $-80^{\circ} \mathrm{C}$. To obtain conidia for fungal inoculation, the blast isolate was cultured on rice bran agar at room temperature $\left(\approx 23^{\circ} \mathrm{C}\right)$ for 8 days before harvesting conidia.

The cultivars of rice (Orzya sative subsp. japonica) used in the study were Drew, Wells, and M201. Whereas Drew is resistant, both Wells and M201 are susceptible to this blast isolate under greenhouse conditions.

Pathogen inoculation. Rice seedlings were grown in a computer-controlled greenhouse at temperatures of $\approx 28^{\circ} \mathrm{C}$ day and $25^{\circ} \mathrm{C}$ night. Two-week-old rice seedlings were spray inoculated with $M$. grisea at a concentration of $2.5 \times 10^{5}$ spores $/ \mathrm{ml}$. After inoculation, the seedlings were first incubated in a dew chamber at $22^{\circ} \mathrm{C}$ for $24 \mathrm{~h}$ at $100 \%$ relative humidity and then returned to the greenhouse. Leaf samples were collected at $0,2,4$, and 6 days postinoculation (DPI), immediately frozen with liquid nitrogen, and then stored at $-80^{\circ} \mathrm{C}$ freezer. Disease was scored in a scale of 0 to 9 at 6 DPI according to the disease rating method described previously (13).

DNA extraction. Fungal mycelia or infected leaf tissue was ground with liquid nitrogen and transferred into a Eppendorf tube containing $400 \mu \mathrm{l}$ of extraction buffer $(0.3 \mathrm{M} \mathrm{NaCl}, 50 \mathrm{mM}$ Tris$\mathrm{HCl}, \mathrm{pH} 7.5,20 \mathrm{mM}$ EDTA, 2\% sarkosyl, 0.5\% sodium dodecyl sulfate, $5 \mathrm{M}$ urea, and 5\% Phenol). Subsequently, $400 \mu \mathrm{l}$ of phenol/chloroform solution (1:1, pH 8.0) was added. After vortexing for $10 \mathrm{~min}$, samples were centrifuged for $5 \mathrm{~min}$ at 14,000 rpm. Supernatants were transferred into a new tube and DNAs were precipitated with 0.7 volume of isopropanol by centrifugation (5 min at 12,000 rpm). Precipitated DNAs were washed with $70 \%$ ethanol, air dried, and dissolved in $40 \mu \mathrm{l}$ of Tris-EDTA (TE) buffer containing RNase at $10 \mu \mathrm{g} / \mathrm{ml}$.
Primer and probe design. A specific pair of DNA primers (forward, 5'-TAC GAG AGG AAC CGC TCA TTC AGA TAA TTA; reverse, 5'-TCA GCA GAT CGT AAC GAT AAA GCT ACT C) were designed based on the $3^{\prime}$ end of the $M$. grisea $28 \mathrm{~S}$ $r D N A$ gene. PCR amplification with this pair of primers yielded a 330-bp fragment that was used as the probe to detect rRNA in northern blot analysis. The $28 \mathrm{~S} r D N A$ gene is present at as many as 100 or more copies per genome in fungi and is constitutively expressed at very high levels; therefore, it would provide very good detection sensitivity at both the DNA and RNA levels $(25,35)$.

Real-time PCR assay. Real-time PCR was performed using a MicroAmp Optical 96-well reaction plate and MicroAmp Optical Caps (PE Biosystems, Foster City, CA) in an ABI Prism 7700 Sequence Detection System (PE Biosystems). Each well contains a $25-\mu$ reaction mixture that includes $12.5 \mu \mathrm{l}$ of $2 \times$ SYBR Green PCR Master Mix (PE Biosystems) and $12.5 \mu \mathrm{l}$ of DNA solution (1 pmole each of forward and reverse primers and $15 \mathrm{ng}$ of rice DNA templates). To construct a standard curve for calculation of the fungal DNA amount and biomass, a series of known amounts of $M$. grisea DNA $\left(1,10^{1}, 10^{2}, 10^{3}\right.$, or $\left.10^{4} \mathrm{pg}\right)$ were mixed with $15 \mathrm{ng}$ of rice DNA isolated from uninfected leaves. Thermal cycling conditions consisted of $10 \mathrm{~min}$ at $95^{\circ} \mathrm{C}$ followed by 40 cycles of $15 \mathrm{~s}$ at $95^{\circ} \mathrm{C}$ and $1 \mathrm{~min}$ at $60^{\circ} \mathrm{C}$.

RNA extraction and northern blot analysis. Total RNAs were extracted from the fungal mycelia or infected leaves using TRIZOL reagent according to the manufacturer's instructions (Life Technologies Inc., Rockville, MD). Total RNA (10 $\mu \mathrm{g}$ ) was fractionated on a $1.2 \%$ agarose gel and blotted onto a nylon membrane (MSI, Westborough, MA). The blots were hybridized with the $\left[\alpha-{ }^{32} \mathrm{P}\right]$ dCTP-labeled 330-bp $r D N A$ fragment of $M$. grisea using Perfect-Hybridization buffer (Sigma-Aldrich, St. Louis) at $68^{\circ} \mathrm{C}$ overnight, and washed at a high stringency as described by the manufacturer. The radioactive signals of hybridized 28S rRNA of $M$. grisea were determined by phosphorimaging (Molecular Dynamics, Sunnyvale, CA). In addition, sample loading was normalized based on rice $25 \mathrm{~S}$ rDNA in the same northern blot. A series of known amounts of $M$. grisea RNAs $(0.2,2,20$, and $200 \mathrm{ng}$ ), together with $10 \mu \mathrm{g}$ of rice RNA from uninfected leaves, were also loaded in RNA gels to construct RNA standard curves for calculation of the fungal RNA amount and biomass.

\section{RESULTS}

Primer specificity and DNA standard curves. The accuracy of PCR-based assays can be significantly affected by the specificity of DNA primers. To evaluate the specificity of the primer pair used in our assays, an agarose gel analysis was performed after 40 cycles of real-time PCR on ABI Prism 7700 Sequence Detection System. The expected 330-bp fragment was only observed with samples containing $10 \mathrm{pg}$ or more of $M$. grisea DNA, but not with samples containing $1 \mathrm{pg}$ of fungal DNA (likely due to low amount of the template) or rice DNA (15 ng) only (Fig. 1A). Furthermore, no additional fragments were visible on the gel. These results indicate that the primer pair was specific for the $28 \mathrm{~S}$ rDNA of $M$. grisea, and not interfered by the presence of rice DNA.

Amplification profiles of the same samples generated with cycle-by-cycle collection of fluorescence are shown in Figure 1B. The $\Delta \mathrm{Rn}$ values for the no-template control and rice DNA control remained at the baseline throughout 40 cycles; therefore, their $\mathrm{Ct}$ values were 40 . In contrast, the $\mathrm{Ct}$ values for the $10^{4}-, 10^{3}-, 10^{2}-$, $10^{1}$-, and 1-pg samples of $M$. grisea DNA were 17.78, 21.01, $26.61,31.75$, and 36.47 , respectively. These results further confirmed that the primer pair was specific to $28 \mathrm{~S}$ rDNA of $M$. grisea and not interfered by the presence of rice DNA.

Following the analysis of amplification profiles, a standard curve was constructed based on the starting amounts $\left(10^{4}, 10^{3}\right.$, 
$10^{2}, 10^{1}$, and $1 \mathrm{pg}$ ) of $M$. grisea DNA (in the presence of $15 \mathrm{ng}$ of rice DNA) versus their $\mathrm{Ct}$ values obtained from real time PCR (Fig. 1C). A linear relationship was observed when $\mathrm{Ct}$ values were plotted against the logs of the initial amounts of $M$. grisea DNA. With this standard curve, each 10-fold difference in initial DNA amounts was represented by approximately five-cycle differences in $\mathrm{Ct}$, and the linearity extended at least over $10^{4}$-fold range. The

A

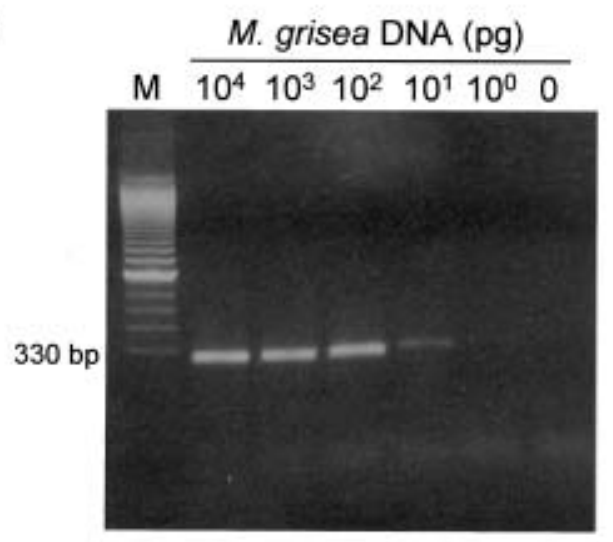

B

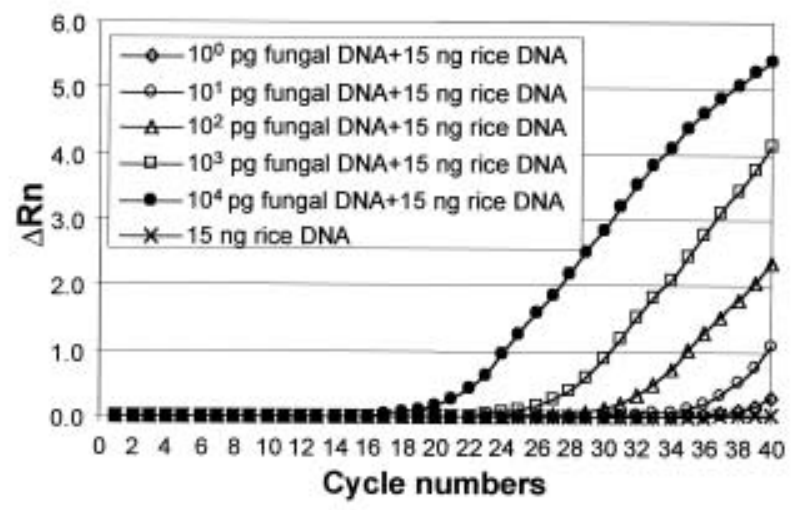

C

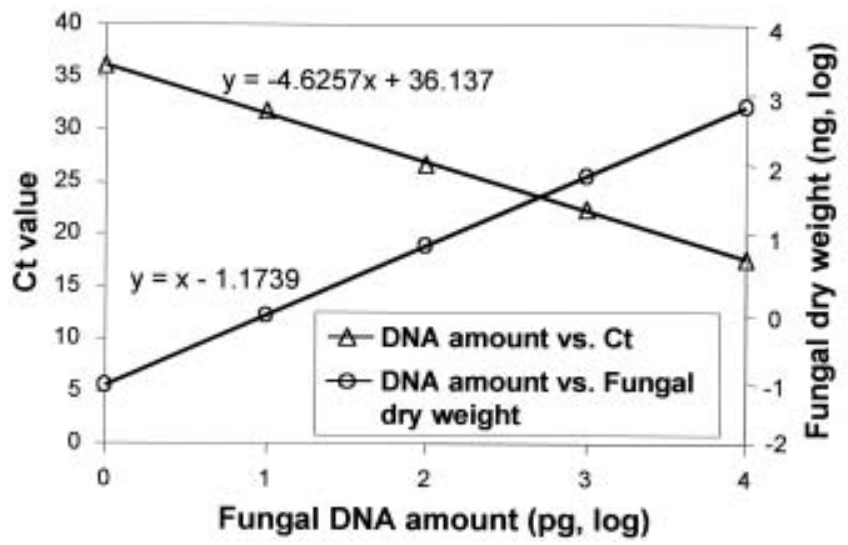

Fig. 1. Real-time polymerase chain reaction (PCR) analysis and construction of DNA standard curves. A, Visual evaluation of real-time PCR products (40 cycles) in a $1 \%$ agarose gel. All samples contained $15 \mathrm{ng}$ of rice DNA in addition to different amounts of $M$. grisea DNA. B, Real-time amplification profiles of Magnaporthe grisea DNA samples generated from cycle-by-cycle collection of fluorescence. A $\Delta \mathrm{Rn}$ value represents a difference in fluorescence intensity between two cycles. A cycle threshold $(\mathrm{Ct})$ value represents a specific cycle number at which the $\Delta \mathrm{Rn}$ value becomes greater than the base line. C, Standard curves for conversion of $\mathrm{Ct}$ values to the fungal DNA amount and biomass. The log of the initial amounts of M. grisea DNA was plotted versus the corresponding $\mathrm{Ct}$ values or fungal dry weights. correlation coefficient $(r)$ for the standard curve was 0.99 (an average from three tests of different DNA sample preparations), indicating that the individual data points were highly correlated with the calculated linear regression. In addition, a standard curve was constructed for conversion of the fungal DNA amount to its biomass (dry weight, Fig. 1C). This was derived according to extractable DNA amounts (from the average of three carefully conducted extractions) in freeze-dried fungal mycelia. The standard curves allowed for the calculation of $M$. grisea DNA amount or biomass in infected rice plants based on the test sample's $\mathrm{Ct}$ values obtained from real-time PCR.

Probe specificity and RNA standard curves. In RNA-based northern blot/phosphoimaging analysis, the 330-bp rDNA fragment amplified by the above primer pair was used as a probe to hybridize RNA blots loaded with various amounts $(0.2,2,20$, and $200 \mathrm{ng}$ ) of $M$. grisea RNA in the presence of $10 \mu \mathrm{g}$ of rice RNA. A hybridizing band was observed in samples with $M$. grisea RNA, but not in the sample with rice RNA only (Fig. 2A). Under our experimental conditions, therefore, the probe was very specific to the $28 \mathrm{~S}$ rRNA of $M$. grisea and was not interfered by rice RNA. Although the radioactive signal for the 0.2-ng $M$. grisea RNA sample was difficult to see on the northern blot (Fig. 2A), it was detectable using phosphorimaging. The average counts of radioactivity for $0.2-, 2-, 20-$, and 200-ng M. grisea RNAs were 77, $180,1,254$, and 6,577, respectively. Following northern blot/phosphoimaging analysis, a standard curve was constructed based on the initial amounts $(0.2,2,20$, and $200 \mathrm{ng})$ of $M$. grisea RNA versus their radioactivity counts (Fig. 2B). The linearity of the standard curve extended at least over $10^{3}$-fold range with a correlation coefficient of 0.99 (an average from three tests of different RNA sample preparations), indicating a high correlation between the individual data points and the calculated linear regression. To convert the fungal RNA amount to biomass, a standard curve was derived according to the extractable RNA amounts (from the average of three carefully conducted extractions) in fungal my-

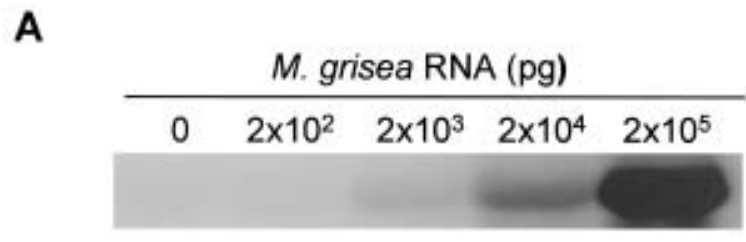

B

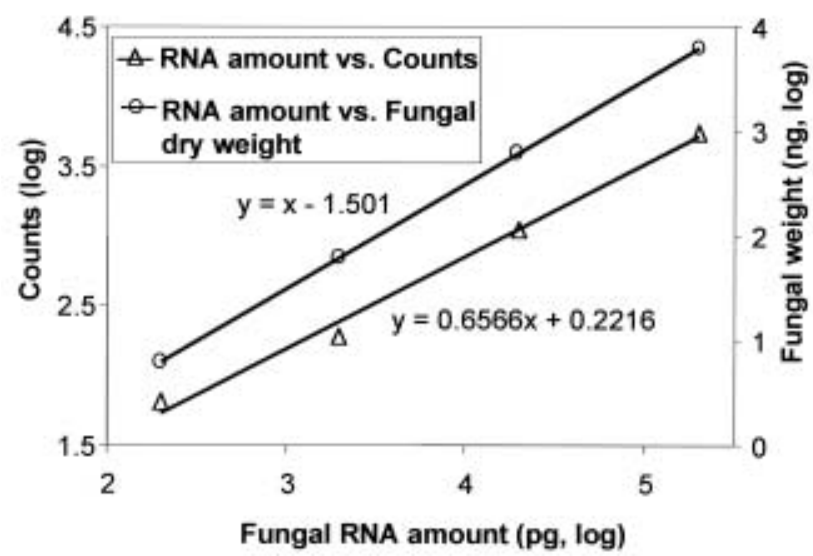

Fig. 2. Northern blot/phosphoimaging analysis and construction of RNA standard curves. A, Magnaporthe grisea RNA blots probed with the $\left[\alpha-{ }^{32} \mathrm{P}\right]$ labeled 330-bp rDNA fragment. All samples contained $10 \mu \mathrm{g}$ of rice RNA in addition to different amounts of $M$. grisea RNA. B, Standard curves for conversion of radioactive counts to the fungal RNA amount and biomass. The $\log$ of the initial amount of $M$. grisea RNA was plotted versus the corresponding radioactive counts or fungal dry weights. 
celia (Fig. 2B). Similar to real-time PCR assays, these RNA standard curves allowed for the calculation of $M$. grisea RNA amount or biomass in rice leaves based on radioactive counts obtained from northern/phosophoimaging analysis.

Reproducibility of real-time PCR and northern blot/phosphoimaging analyses. A reliable assay requires small variation and good reproducibility. In an effort to validate the reproducibility of the real-time PCR method, PCR amplifications were conducted using DNAs from three different preparations. The $M$. grisea DNAs obtained from three different preparations all were quantified with an ultraviolet spectrophotometer. Subsequently, real-time PCR was performed with $10^{4}$ and $10^{2} \mathrm{pg}$ of $M$. grisea DNAs. Highly reproducible $\mathrm{Ct}$ values with very small standard deviation were observed among triplicate samples and three different preparations (Table 1). The standard deviation of $\mathrm{Ct}$ values within the triplicates is $\approx 0.02$ to 0.12 and 0.06 to 0.08 for $10^{4}$ and $10^{2} \mathrm{pg}$ of DNA samples, respectively. The standard deviation of $\mathrm{Ct}$ values among three different sample preparations was 0.23 and 0.72 for $10^{4}$ and $10^{2} \mathrm{pg}$ of DNA samples, respectively. Relatively large variation at the lower concentration of DNA was probably due to stochastic effects that reduced the precise quantification of PCR. These results demonstrate that amplifications by real-time PCR are not only highly reproducible within replicates of the same sample preparation but also very reproducible among different sample preparations. We suggest that at least $10^{2} \mathrm{pg}$ of total DNA should be used to reduce potential stochastic effects and to obtain more reliable results.

To verify the reproducibility of northern blot/phosphoimaging analysis, total RNAs were extracted separately from three different samples of $M$. grisea and quantified with an ultraviolet spectrophotometer. Northern blot/phosphoimaging analysis was then performed using 200 and $2 \mathrm{ng}$ of $M$. grisea RNAs from each sample preparation. The standard deviation of radioactivity counts within triplicates of the same sample preparation was 270 to 437 and 11 to 19 for 200 and 2 ng of $M$. grisea RNA samples, respectively (Table 2). The standard deviation among three different sample preparations was 356 and 14 counts for 200 and $2 \mathrm{ng}$ of $M$. grisea RNA, respectively. Therefore, data from RNA blot/phosphoimaging analysis have a good reproducibility within replicates from the same preparation or from three different preparations. However, it has a relatively larger standard deviation (5.7 to $8.1 \%$ of the mean) than that of the real-time PCR method (1.3 to $2.7 \%$ of the mean).

Determination of $M$. grisea growth in infected rice leaves. In order to demonstrate and compare these two methods for quantification of the fungal growth in planta, a blast isolate belonging to the IC-17 pathotype was inoculated onto two susceptible (M201 and Wells) and one resistant (Drew) rice cultivars. Six days after inoculation, broad spindle-shaped expanding lesions developed on the M201 and Wells cultivars. Both M201 and Wells were rated 6.0 on the 0 -to- 9 scale rating for their disease severity. In contrast, small reddish lesions developed on the Drew cultivar. The hypersensitive reaction on Drew was rated 2.0 on the 0 -to- 9 scale rating. To quantify the fungal infection, total DNAs were extracted from infected rice leaves at 0,2,4, and 6 DPI. The fungal DNA amount (or fungal biomass) in infected leaves was calculated using DNA standard curves (Fig. 1C) after determining the $\mathrm{Ct}$ values by real-time PCR. The infection was very restricted in resistant cv. Drew up to 6 DPI (Fig. 3). However, infection was detectable in susceptible cvs. M201 and Wells at 2 DPI. At 4 and 6 DPI, the growth of $M$. grisea was $\approx 46$ and 66 times higher in M201 than in Drew, respectively.

Northern blot/phosphoimaging analysis was also used to quantify the infection of $M$. grisea in rice plants. The total RNAs extracted from infected leaves were blotted onto a nylon membrane and probed with a $\left[\alpha^{32} \mathrm{P}\right]$-labeled 330-bp rDNA fragment of $M$.

TABLE 1. Amplification reproducibility of the real-time polymerase chain reaction (PCR) from three independent DNA preparations ${ }^{\mathrm{a}}$

\begin{tabular}{|c|c|c|c|c|c|c|}
\hline \multirow[b]{2}{*}{ Sample preparations } & \multicolumn{3}{|c|}{10 ng DNA } & \multicolumn{3}{|c|}{$0.1 \mathrm{ng}$ DNA } \\
\hline & $\mathrm{Ct}$ & Mean & Standard deviation & $\mathrm{Ct}$ & Mean & Standard deviation \\
\hline \multirow[t]{3}{*}{1} & 17.50 & $\ldots$ & $\ldots$ & 25.81 & $\ldots$ & $\ldots$ \\
\hline & 17.52 & $\ldots$ & $\ldots$ & 25.83 & $\ldots$ & $\ldots$ \\
\hline & 17.53 & 17.52 & 0.02 & 25.93 & 25.86 & 0.06 \\
\hline \multirow[t]{3}{*}{2} & 18.00 & $\ldots$ & $\ldots$ & 26.92 & $\ldots$ & $\ldots$ \\
\hline & 17.79 & $\ldots$ & $\ldots$ & 27.01 & $\ldots$ & $\ldots$ \\
\hline & 17.99 & 17.93 & 0.12 & 26.85 & 26.93 & 0.08 \\
\hline \multirow[t]{4}{*}{3} & 17.84 & $\ldots$ & $\ldots$ & 27.21 & $\ldots$ & $\ldots$ \\
\hline & 17.86 & $\ldots$ & $\ldots$ & 27.19 & $\ldots$ & $\ldots$ \\
\hline & 17.89 & 17.86 & 0.03 & 27.32 & 27.24 & 0.07 \\
\hline & $\ldots$ & 17.77 & 0.23 & $\ldots$ & 26.68 & 0.72 \\
\hline
\end{tabular}

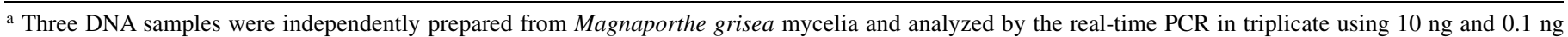
DNAs. The standard deviations in the last line of the table represent variations between samples. The real-time PCR assays were repeated once using exactly the same DNA samples and replicates and yielded nearly identical results. $\mathrm{Ct}=$ cycle threshold.

TABLE 2. Reproducibility of the northern blot/phosphoimaging analysis from three independent RNA preparations ${ }^{\mathrm{a}}$

\begin{tabular}{|c|c|c|c|c|c|c|}
\hline \multirow[b]{2}{*}{ Sample preparations } & \multicolumn{3}{|c|}{200 ng RNA } & \multicolumn{3}{|c|}{2 ng RNA } \\
\hline & Count & Mean & Standard deviation & Count & Mean & Standard deviation \\
\hline \multirow[t]{3}{*}{1} & $6,296.33$ & $\ldots$ & $\ldots$ & 166.85 & $\ldots$ & $\ldots$ \\
\hline & $6,835.87$ & $\ldots$ & $\ldots$ & 152.74 & $\ldots$ & $\ldots$ \\
\hline & $6,598.67$ & $6,576.96$ & 270.42 & 178.97 & 166.18 & 13.13 \\
\hline \multirow[t]{3}{*}{2} & $5,814.13$ & $\ldots$ & $\ldots$ & 146.65 & $\ldots$ & $\ldots$ \\
\hline & $6,642.58$ & $\ldots$ & $\ldots$ & 136.65 & $\ldots$ & $\ldots$ \\
\hline & $5,987.58$ & $6,148.09$ & 436.93 & 158.99 & 147.13 & 11.19 \\
\hline \multirow[t]{4}{*}{3} & $6,109.39$ & $\ldots$ & $\ldots$ & 192.30 & $\ldots$ & $\ldots$ \\
\hline & $5,513.45$ & $\ldots$ & $\ldots$ & 154.10 & $\ldots$ & $\ldots$ \\
\hline & $5,986.56$ & $5,869.80$ & 314.66 & 178.60 & 174.90 & 19.40 \\
\hline & $\ldots$ & $6,198.28$ & 356.24 & $\ldots$ & 176.20 & 14.20 \\
\hline
\end{tabular}

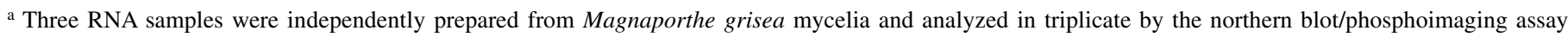
using 200- and 2-ng RNAs. The standard deviations in the last line of the table represent variations between samples. The northern blot/phosphoimaging analyses were repeated once using the exactly same RNA samples/replicates and yielded nearly identical results. 
grisea (Fig. 4A). After determining radioactive counts by phosphoimaging analysis, the fungal RNA amounts (or fungal growth) in infected leaves were readily calculated using RNA standard curves (Fig. 4).

To validate and compare these two methods, the DNA and RNA amounts of $M$. grisea in rice were converted to fungal biomass (dry weight) using the standard curves in Figures $1 \mathrm{C}$ and $2 \mathrm{~B}$. Both

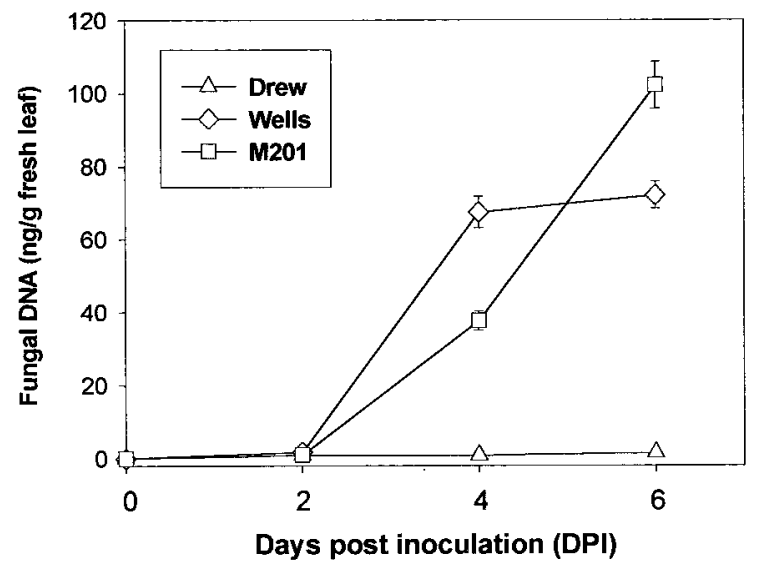

Fig. 3. Growth of Magnaporthe grisea in seedling leaves of resistant (Drew) and susceptible (M201 and Wells) rice cultivars as measured by the fungal DNA amounts using the real-time polymerase chain reaction analysis. Each data point represents the average and standard deviation of three DNA samples from a single cultivar at a specific time $(0,2,4$, or 6 days postinoculation). Leaf samples were collected from rice seedlings grown in three large trays (total nine trays for three cultivars). Each sample contained pooled leaves collected from six infected seedlings grown in the same tray. The experiment was repeated once with similar results.

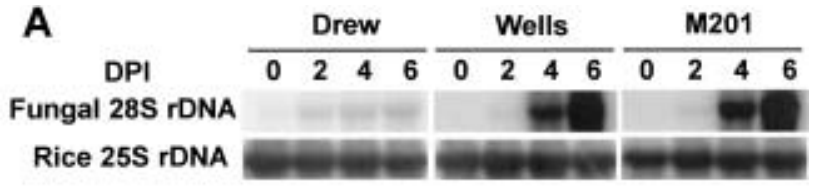

B

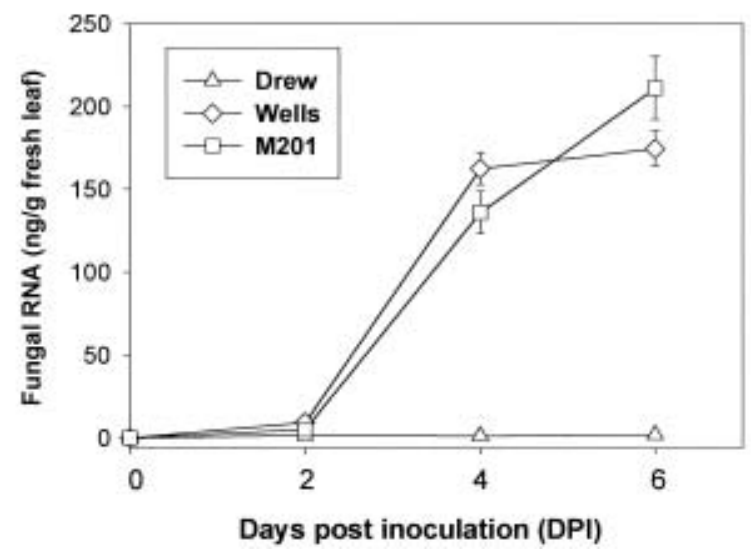

Fig. 4. Determination of Magnaporthe grisea growth in infected rice leaves using northern blot/phosphoimaging analysis. A, RNA blots (10 $\mu \mathrm{g}$ total RNA per lane) probed with radiolabeled $M$. grisea $r D N A$ and rice $25 \mathrm{~S} r D N A$, respectively. B, Growth of $M$. grisea in seedling leaves of resistant (Drew) and susceptible (M201 and Wells) cultivars as measured by the fungal RNA amounts. Each data point represents the average and standard deviation of three RNA samples from a single cultivar at a specific time $(0,2,4$, or 6 days postinoculation). Leaf samples were collected from rice seedlings grown in three large trays (total nine trays for three cultivars). Each sample contained pooled leaves collected from six infected seedlings grown in the same tray. The experiment was repeated once with similar results. real-time PCR and northern blot/phosphoimaging analysis gave very similar results with regard to the fungal biomass or growth of $M$. grisea in rice leaves in nearly all the measurements, indicating that these two methods are compatible and corroborate each other (Fig. 5). The discrepancy of the fungal biomass measured by the two methods at 4 DPI in M201 is likely due to sampling variations because not exactly the same leaves (but very similar samples from the same pots) were used in the real-time PCR and northern blot/phosphoimaging analyses. The efficiency of DNA and RNA extractions also may contribute to the descrepancy.

\section{DISCUSSION}

During the past several decades, the $O$. sativa-M. grisea interaction has been extensively studied because of its significant impact on worldwide rice production. As an excellent model system for studying cereal pathology, the entire genomes of both rice and $M$. grisea are now being sequenced. Although attempts have been made to detect and quantify the rice blast fungus using Southern hybridization and monoclonal antibody-based immunoassay (29, 42), to our knowledge, no adequate method has been developed to accurately quantify the growth of $M$. grisea in planta. In this study, we have evaluated the real-time PCR and northern blot/ phosphoimaging analyses for quantification of $M$. grisea in rice plants. Our results show that both methods yielded comparable data and provide a sensitive and reliable measurement of $M$. grisea biomass in vitro or in planta. Most recently, the real-time PCR approach has been employed to quantify the growth of Phytophthora spp. in host plants (6) and to monitor Pyrenophora infection in barley seed $(2,3)$. However, this is the first time that both DNA-based real-time PCR and RNA-based northern blot/ phosphoimaging analyses were utilized and directly compared for the quantification of a fungal plant pathogen.

In comparison to the traditional disease rating that is based on blast lesion size and number, the DNA-based real-time PCR approach allows a more accurate calculation of relative growth and absolute biomass of $M$. grisea. However, the amount of fungal growth in planta may not always be proportional to the development of disease symptoms elicited by different blast isolates. Therefore, both quantification of the fungal growth and phenotypic assessment of disease symptoms are needed to more precisely evaluate virulence or aggressiveness of different blast isolates or mutants. Using our methods, blast resistance levels of different rice cultivars also can be more accurately evaluated (Figs. 3 to 5). When lesions just became visible at 4 DPI, the growth of $M$. grisea was 80 times higher in the susceptible cv. Wells than in the resistant cv. Drew, which carries a Pita resis-

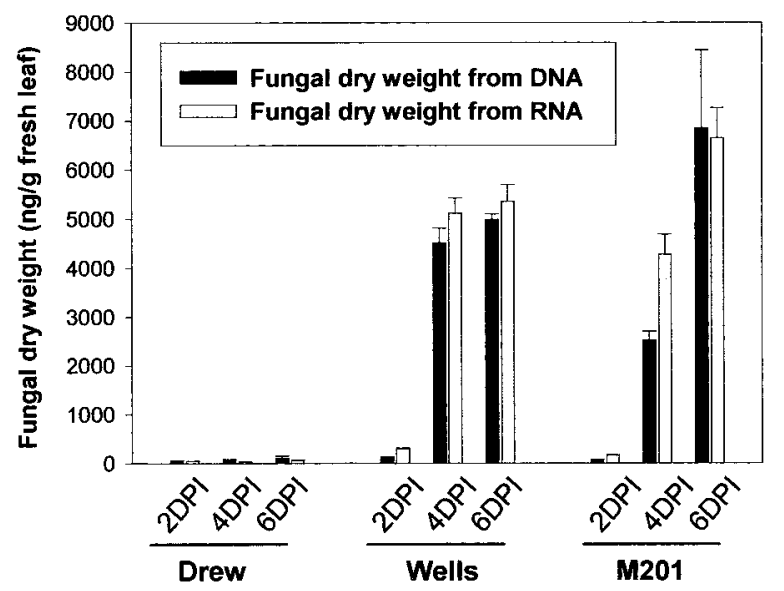

Fig. 5. Comparison between the real-time polymerase chain reaction and northern blot/phosphoimaging analyses for quantification of Magnaporthe grisea growth based on the calculated fungal biomass in rice seedlings. 
tance gene. Due to its high sensitivity and reproducibiliy, the realtime PCR method will be ideal for detecting minor changes of resistance or susceptibility in particular transgenic plants or mutants. Real-time PCR can be rapidly performed (usually within $3 \mathrm{~h}$ ); therefore, it is more amenable for high-throughput analysis of a large number of samples. In contrast, northern blot/phosphoimaging analysis is relatively slow and more labor intensive. However, it may have an advantage to the investigators who study the expression of defense-related genes during disease resistance response. In these cases, both levels of defense gene expression and disease resistance (e.g., relative growth of $M$. grisea) can be accurately quantified and correlated using the same RNA blots prepared from same leaf samples.

To enhance the detection sensitivity, our PCR primers were designed based on the $3^{\prime}$ region of $28 \mathrm{~S} M$. grisea rDNA that exists in multiple copies in the fungal genome. In addition, the 330-bp rDNA fragment amplified by the same pair of primers was used as a probe for the northern blot/phosphoimaging analysis in order to minimize potential variations between two assay methods. Consistent results were obtained with both methods using these $r D N A$ primers and probe. Under our experimental conditions, we have not observed any complications (e.g., cross-reaction or crosshybridization) with the leaf samples from growth chamber and greenhouse tests. The rDNA sequences are well conserved within closely related species and genera; therefore, the primers and probe may detect and quantify other related fungi that coexist in rice plants. Thus, extra care must be taken if the above primers and probe are to be used for analyzing leaf samples from rice fields. It will be more prudent to design highly specific primers for the real-time PCR detection and quantification of $M$. grisea in field samples. The protocol utilizes the double-stranded DNA dye SYBR Green I for detection of amplified products, it should be readily adaptable to any existing primer sets that are more specific for the blast fungus.

\section{LITERATURE CITED}

1. Bao, J. R., Velema, J., Dobinson, K. F., and Lazarovits, G. 2000. Using GUS expression in a nonpathogenic Fusarium oxysporum strain to measure fungal biomass. Can. J. Plant Pathol. 22:70-78.

2. Bates, J. A., and Taylor, E. J. A. 2001. Scorpion ARMS primers for SNP real-time PCR detection and quantification of Pyrenophora teres. Mol. Plant Pathol. 2:275-280.

3. Bates, J. A., Taylor, E. J. A., Kenyon, D. M., and Thomas, J. E. 2001. The application of real time PCR to the identification, detection, and quantification of Pyrenophora species in barley seed. Mol. Plant Pathol. 2:49-57.

4. Benito, E. P., Ten Have, A., Van Klooster, J. W., and Van Kan, J. A. L. 1998. Fungal and plant gene expression during synchronized infection of tomato leaves by Botrytis cinerea. Eur. J. Plant Pathol. 104:207-220.

5. Bermingham, S., Maltby, L., and Cook, R. C. 1995. A critical assessment of the validity of ergosterol as an indicator of fungal biomass. Mycol. Res. 99:479-484.

6. Böhm, J., Hahn, A., Schubert, R., Bahnweg, G., Adler, N., Nechwatal, J., Oehlmann, R., and Obwald, W. 1999. Real-time quantitative PCR: DNA determination in isolated spores of the mycorrhizal fungus Glomus mosseae and monitoring of Phytophthora infestans and Phytophthora citriola in their respective host plant. J. Phytopathol. 147:409-416.

7. Couteaudier, Y., Daboussi, M. J., Eparvier, A., Langin, T., and Orcival, J. 1993. The GUS gene fusion system (Escherichia coli $\beta$-D-glucuronidase gene), a useful tool in studies of root colonization by Fusarium oxysporum. Appl. Environ. Microbiol. 59:1767-1773.

8. Dewey, F. M., Thornton, C. R., and Gilligan, C. A. 1997. Use of monoclonal antibodies to detect, quantify, and visualize fungi in soil. Adv. Bot. Res. 24:276-308.

9. Frederick, R. D., Snyder, K. E., Tooley, P. W., Berthier-Schaad, Y., Peterson, G. L., Bonde, R. R., Schaad, N. W., and Knorr, D. A. 2000. Identification and differentiation of Tilletia indica and T. walkeri using the polymerase chain reaction. Phytopathology 90:951-960.

10. Gardner, R. M., Tindall, G. W., Cline, S. M., and Brown, K. L. 1993. Ergosterol determinationin activated sludge and its application as a biochemical marker for monitoring fungal biomass. J. Microbiol. Methods 17:49-60.
11. Gretenkort, M. A., and Ingram, D. S. 1993. The use of ergosterol as a quantitative measure of the resistance of cultured tissues of Brassica napus ssp. Oleifera to Leptosphaeria maculans. J. Phytopathol. 138:217224.

12. Groppe, K., and Boller, T. 1997. PCR assay based on a microsatellitecontaining for detection and quantification of Epichoe endophytes in grass tissue. Appl. Environ. Microbiol. 63:1543-1550.

13. Harp, T. L., and Correll, J. C. 1998. Recovery and characterization of spontaneous, selenate-resistant mutants of Magnaporthe grisea, the rice blast pathogen. Mycologia 90:954-963.

14. Harrison, J. G., Barker, H., Lowe, R., and Rees, E. A. 1990. Estimation of amounts of Phytophthora infestans mycelium in leaf tissue by enzyme-linked immunosorbent assay. Plant Pathol. 34:557-564.

15. Heild, C. A., Stevens, J., Livak, K. J., and Williams, P. M. 1996. Real time quantitative PCR. Genome Methods 6:986-994.

16. Henson, J. M., and French, R. 1993. The polymerase chain reaction and plant disease diagnosis. Annu. Rev. Phytopathol. 31:81-109.

17. Howard, R. J., Ferrari, M., Roach, D. H., and Money, N. P. 1991. Penetration of hard substrates by a fungus employing enormous turgor pressures. Proc. Natl. Acad. Sci. USA 88:11281-11284.

18. Hu, X., Nazar, R. N., and Robb, J. 1993. Quantification of Verticillium biomass in wilt disease development. Physiol. Mol. Plant Pathol. 42:23-36.

19. Judelson, H. S., and Tooley, P. W. 2000. Enhanced polymerase chain reaction methods for detecting and quantifying Phytophthora infestans in plants. Phytopathology 90:1112-1119.

20. Kamoun, S., van West, P., and Govers, F. 1998. Quantification of late blight resistance of potato using transgenic Phytophthora infestans expressing $\beta$-glucuronidase. Eur. J. Plant Pathol. 104:521-525.

21. Karpovich-Tate, N., Spanu, P., and Dewey, F. M. 1998. Use of monoclonal antibodies to determine biomass of Cladosporium fulvum in infected tomato leaves. Mol. Plant-Microbe Interact. 11:710-716.

22. Liljeroth, E., Jansson, B. H., and Schafer, W. 1993. Transformation of Bipolaris sorokiniana with the GUS gene and use for studying fungal colonization of barley roots. Phytopathology 83:1484-1489.

23. Mahe, A., Grisvard, J., and Dron, M. 1992. Fungal- and Plant-specific gene markers to follow the bean anthracnose infection process and normalize a bean chitinase mRNA induction. Mol. Plant-Microbe Interact. 5:242-248.

24. Mahuku, G. S., Goodwin, P. H., and Hall, R. 1995. A competitive polymerase chain reaction to quantify DNA of Leptosphaeria maculans during blackleg development in oilseed rape. Mol. Plant-Microbe Interact. 8:761-767.

25. Maleszka, R., and Clark-Walker, G. D. 1993. Yeasts have a four-fold variation in ribosomal DNA copy number. Yeast 9:53-58.

26. Martin, F., Delaruelle, A., and Hilberty, J. L. 1990. An improved ergosterol assay to estimate fungal biomass in ectomycorrhizas. Mycol. Res. 94:1059-1064.

27. Molina, A., Hunt, M. D., and Ryals, J. A. 1998. Impaired fungicide activity in plants blocked in disease resistance signal transduction. Plant Cell 10:1903-1914.

28. Mumford, R. A., Walsh, K., Barker, I., and Boonham, N. 2000. Detection of potato mop top virus and tobacco rattle virus using a multiplex realtime fluorescent reverse-transcription polymerase chain reaction assay. Phytopathology 90:448-453.

29. Nannapaneni, R., Gergerich, R. C., and Lee, F. N. 2000. Technology for rapid detection, identification, and quantification of rice blast fungus Pyricularia grisea. Ark. Agric. Exp. Stn. Res. Ser. 476:480-485.

30. Newton, A. C., and Reglinski, T. 1993. An enzyme-linked immunosorbent assay for quantifying mildew biomass. J. Plant Dis. Prot. 100:176179.

31. Oliver, R. P., Farman, M. L., Jones, J. D. G., and Hammond-Kosack, K. E. 1993. Use of fungal transformants expressing beta-glucuronidase activity to detect infection and measure hyphal biomass in infected plant tissues. Mol. Plant-Microbe Interact. 6:521-525.

32. Pacovsky, R. S., and Bethlenfalvay, G. J. 1982. Measurement of the extraradical mycelium of a vescular-arbuscular mycorrhizal fungus in soil by chitin determination. Plant Soil 68:143-147.

33. Plassard, C. S., Mousain, D. G., and Salsac, L. E., 1982. Estimation of mycelia growth of basidiomycetes by means of chin determination. Phytochemistry 21:345-348.

34. Roberts, C. A., Dietzgen, R. G., Heelan, L. A., and Maclean, D. J. 2000. Real time PCR fluorescent detection of tomato spotted wilt virus. J. Virol. Methods 88:1-8.

35. Sandhu, G. S., Kline, B. C., Stockman, L., and Roberts, S. D. 1995. Molecular probes for diagnosis of fungal infections. J. Clin. Microbiol. 33:2913-2919.

36. Schaad, N. W., Berthier-Schaad, Y., Sechler, A., and Knorr, D. 1999. Detection of Clavibacter michiganensis sbusp. Sepedonicus in potato tubers by BIO-PCR and an automated real-time fluorescence detection 
system. Plant Dis. 83:1095-1100.

37. Schweizer, P., Buchala, A., Dudler, R., and Métraux, J. P. 1998. Induced systemic resistance in wounded rice plants. Plant J. 14:475-481.

38. Smith, J. A., and Métraux, J.-P. 1991. Pseudomonas syringae pv. syringae induces systenic resistance to Pyricularia oryzae in rice. Physiol. Mol. Plant Pathol. 39:451-461.

39. Srivastava, A. K., and Arora, D. K. 1997. Evaluation of a polyclonal antibody immunoassay for detection and quantification of Macrophomina phaseolina. Plant Pathol. 46:785-794.

40. Stahl, D. S., and Parkin, T. B. 1996. Relationship of soil ergosterol concentration and fungal biomass. Soil Biol. Biochem. 28:847-855.

41. Takenaka, S. 1995. Dynamics of fungal pathogens in host plant tissues. Can. J. Bot. 73:S1275-S1283.

42. Talbot, N. J., Ebbole, D. J., and Hamer, J. E. 1993. Identification and characterization of MPG1, a gene involved in pathogenicity from the rice blast fungus Magnaporthe grisea. Plant Cell 5:1575-1590.
43. Thomma, B. P. H. J., Tadesse, Y. S. H., and Jacobs, M. 2000. Disturbed correlation between fungal biomass and $\beta$-glucuronidase activity in infections of Arabidopsis thaliana with transgenic Alternaria brassicicola. Plant Sci. 148:31-36.

44. Thrane, C., Lubeck, M., Green, H., Degefu, Y., Allerup, S., Thrane, U., and Jensen, D. F. 1995. A tool for monitoring Trichoderma harzianum: I. Transformation with the GUS gene by protoplast technology. Phytopathology 85:1428-1435.

45. Ward, E., Tahiri-Alaoui, A., and Antoniw, J. F. 1998. Applications of PCR in fungal-plant interactions. Pages 289-307 in: Application of PCR in Mycology. P. D. Bridge, D. K. Arora, C. A. Reddy, and R. P. Elander, eds. CAB International, London, UK.

46. Weller, S. A., Elphinstone, J. G., Smith, N. C., Boonham, N., and Stead, D. E. 2000. Detection of Ralstonia solanacearum strains with a quantitative, multiplex, real-time, fluorogenic PCR (TaqMan) assay. Appl. Environ. Microbiol. 66:2853-2858. 